Bangladesh J. Sci. Res. 28(1): 17-26, 2015 (June)

\title{
EFFECTS OF BIOCHAR ON THE FATE OF THE HEAVY METALS Cd, Cu, Pb AND Zn IN SOIL
}

\author{
K. T. Khan, M. T. A. Chowdhury and S. M. Imamul Huq ${ }^{1}$ \\ Bangladesh-Australia Centre for Environmental Research, Department of Soil, Water and \\ Environment, University of Dhaka, Dhaka-1000, Bangladesh
}

\begin{abstract}
An in vitro incubation study was conducted with soil having seven applications of different treatments of biomass and biochar including a control. The biochar and biomasses were applied at a rate of $5 \mathrm{t} \mathrm{ha}^{-1}$ and incubated at field moisture condition for 30, 60 and 90 days individually in different pots. 0.005M DTPA and $1 \mathrm{M} \mathrm{HCl}$ extractable cadmium (Cd), copper $(\mathrm{Cu})$, lead $(\mathrm{Pb})$ and zinc $(\mathrm{Zn})$ contents were determined at 30, 60 and 90 days of incubation. The phytoavailable fraction of $\mathrm{Cd}, \mathrm{Cu}, \mathrm{Pb}$ and $\mathrm{Zn}$ as extracted with the 0.005M DTPA revealed that biochar did not retain any substantial amount of any of these metals. $1 \mathrm{M} \mathrm{HCl}$ extracted higher amounts of heavy metals than 0.005M DTPA. Neither biochar nor its source biomass had any sorptive effect on the labile fraction of $\mathrm{Pb}$ and $\mathrm{Cd}$ present in soil. $1 \mathrm{M} \mathrm{HCl}$ extracted not only a portion of these metals from the soils but also that present in the biochar and biomass. The general idea that biochars are able to complex metal ions on their surfaces and therefore, reduce bioavailability, however, was not reflected in the present study.
\end{abstract}

Key words: Heavy metals, Biochar, Soil health, 0.005M DTPA extraction

\section{Introduction}

Heavy metal contamination is a widespread occurrence worldwide. These heavy metals are very important contaminants in the environment, especially in the industrial areas. However, agriculture and other anthropogenic activities are also directly or indirectly responsible for heavy metal contamination. Heavy metal contamination in soil is a very serious problem in our country, especially for the agricultural lands. The most important contaminants are cadmium (Cd), copper $(\mathrm{Cu})$, chromium $(\mathrm{Cr})$, lead $(\mathrm{Pb})$, mercury $(\mathrm{Hg})$, nickel $(\mathrm{Ni})$, zinc $(\mathrm{Zn})$. These heavy metals from the contaminated soils could become bioavailable and/or phytoavailable and may enter into the food chain through their accumulation in vegetables, fruits, cereal crops and ultimately ends up in human and animal bodies causing various disorders. Besides, presence of these metals in the soil also hampers the quality of the soils.

Biochar is a carbon-rich by-product of biological origin produced by pyrolysis. It is promoted by scientists and policy makers for its impending role in carbon sequestration, reducing greenhouse gas emissions, renewable energy, waste mitigation, and as a soil ameliorator. It is also believed that biochar can significantly reduce the availability of heavy metals in soil, and decrease $\mathrm{Cd} / \mathrm{Pb}$ content in rice grain (Cui et al. 2011). Biochar application caused decrease in exchangeable Al, soluble Fe, exchangeable K, exchangeable Ca (Masulili et al. 2010), and available Ca and Mg

\footnotetext{
${ }^{1}$ Corresponding author: <imamhuq@hotmail.com>.
} 
(Web 1). Biochar application can also significantly reduce the availability of trace elements to plants. Biochar can significantly immobilize heavy metals such as $\mathrm{Cd}, \mathrm{Zn}$ and $\mathrm{Pb}$ in soil (Beesley et al. 2010, Cao et al. 2011).Biochars are able to complex metal ions on their surfaces and therefore, reduce their bioavailability (Beesley et al. 2011)

Understanding the behaviors of biochars to avoid ecotoxilogical impacts, the effects on nutrient and contaminant (e.g. Heavy metals) behavior and transport are some of the areas that require attention. Considering all these facts, it seems pertinent to look into the effects of biochar on the soil heavy metals vis-à-vis the traditional method of maintaining soil health by application of undecomposed or partially decomposed organic matter. The present study was thus conducted to see the effect of biochar on heavy metal extractability by two different extractants viz., $0.005 \mathrm{M}$ DTPA and $1 \mathrm{M} \mathrm{HCl}$.

\section{Materials and Method}

Surface soil $(0-15 \mathrm{~cm})$ was collected from vegetable fields in Jagir Dighulia village, Atigram union, Manikganj Sadar, Manikganj district. The geo-location of the sampling site is $23^{\circ} 51.884 \mathrm{~N}$ and $90^{\circ} 06.219 \mathrm{E}$ (Fig. 1). The soil was a non-calcareous grey floodplain belonging to the Melandah series.

The collected soil samples were processed following the methods described in Huq and Alam (2005).

Procurement, processing and preparation of biochar has been described in (Mahmud et al. 2014, Khan and Huq 2014, Khan et al. 2014). The designation and lists of the biomass and biochars are presented in Table 1.

$500 \mathrm{~g}$ sized plastic pots were procured from local market. Preparation of the pots for incubation study has been described in Khan et al. (2014). The treatment combinations are presented in Table 2.

Table 1. List of biomasses and biochars with designation.

\begin{tabular}{llll}
\hline Biomass & Designation & Biochar from the corresponding biomass & Designation \\
\hline Rice husk & BM1 & Biochar 1 & BC1 \\
Rice straw & BM2 & Biochar 2 & BC2 \\
Saw dust & BM3 & Biochar 3 & BC3 \\
\hline
\end{tabular}

Total $\mathrm{Cd}, \mathrm{Cu}, \mathrm{Pb}$ and $\mathrm{Zn}$ in the samples of soil and biomass and biochars were determined by atomic absorption spectrophotometer after digesting samples with ternary acid mixture. Extractable $\mathrm{Cd}, \mathrm{Cu}, \mathrm{Pb}$ and $\mathrm{Zn}$ present in the samples of soil (pre- and post - experiment) were determined by atomic absorption spectrophotometer after extracting the samples with $0.005 \mathrm{M}$ DTPA for phytoavailable fraction and $1 \mathrm{M} \mathrm{HCl}$ for weak acid extractable fraction (Table 3). 
Table 2. Treatment description and symbol

\begin{tabular}{llll}
\hline Treatment no. & Treatment symbol & Description & Rate of Application \\
\hline 1. & $\mathrm{~T}_{\mathrm{C}}$ & Control & - \\
2. & $\mathrm{~T}_{\mathrm{BM} 1}$ & Rice husk (BM1) & 5 tons/ha \\
3. & $\mathrm{~T}_{\mathrm{BM} 2}$ & Rice straw (BM2) & $5 "$ \\
4. & $\mathrm{~T}_{\mathrm{BM} 3}$ & Saw dust (BM3) & $5 "$ \\
5. & $\mathrm{~T}_{\mathrm{BC} 1}$ & Biochar from Rice husk (BC1) & $5 "$ \\
6. & $\mathrm{~T}_{\mathrm{BC} 2}$ & Biochar from Rice straw (BC2) & $5 "$ \\
7. & $\mathrm{~T}_{\mathrm{BC} 3}$ & Biochar from Saw dust (BC3) & $5 "$ \\
\hline
\end{tabular}

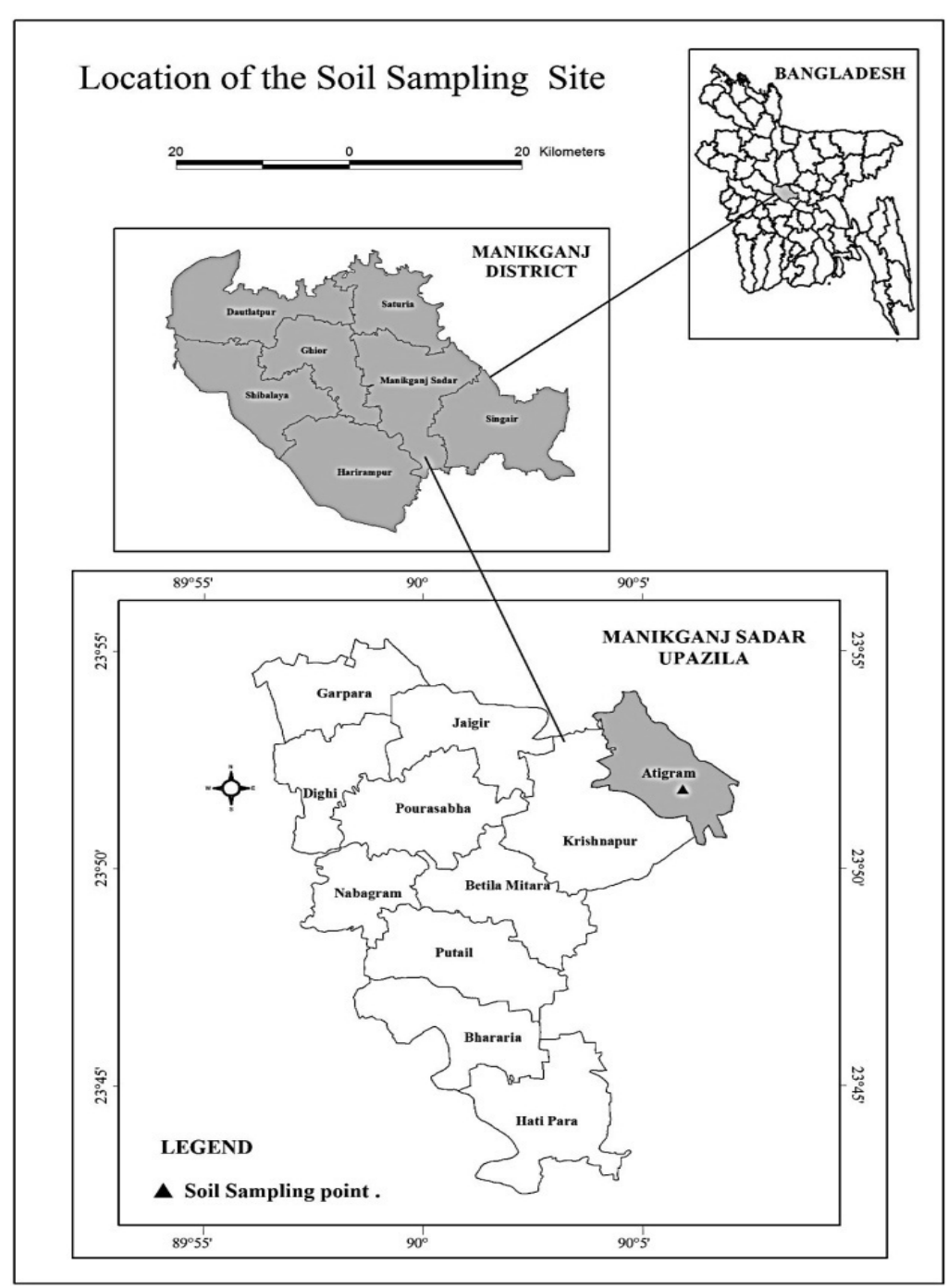

Fig. 1. GPS-GIS based location map of the contaminated soil sampling site. 
All data were statistically analyzed by using Microsoft Excel 2010 and/or MINITAB (Version 16.2).

Table 3. List of extraction method.

\begin{tabular}{lllll}
\hline \multicolumn{5}{c}{ Extractable heavy metals (Cd, Cu, Pb and Zn) } \\
\hline Extractant type & Extractants & Reason for using & Soil : Extractant & Reference \\
\hline $\begin{array}{l}\text { 1. Dilute solutions of } \\
\text { strong acids (1 M HCl) }\end{array}$ & $1 \mathrm{M} \mathrm{HCl}$ & $\begin{array}{l}\text { Release elements from } \\
\text { non-residual metals as } \\
\text { well as in the silicate } \\
\text { mineral matrix. }\end{array}$ & $\begin{array}{l}\text { Time: } 2 \text { hrs } \\
\text { ANZECC and }\end{array}$ & $\begin{array}{l}\text { ARM-CANZ } \\
\text { (2000) }\end{array}$ \\
\hline $\begin{array}{llll}\text { 2. Complexing extractant } \\
(0.005 \text { M DTPA) }\end{array}$ & $0.005 \mathrm{M}$ DTPA & $\begin{array}{l}\text { Release organically- } \\
\text { bound ions or nutrients }\end{array}$ & $\begin{array}{l}1: 2 \\
\text { Time: } 2 \text { hrs }\end{array}$ & $\begin{array}{l}\text { Lindsay and } \\
\text { Norvell } \\
\text { (1978) }\end{array}$ \\
\hline
\end{tabular}

\section{Results and Discussion}

The soil used in this experiment was analyzed for its heavy metal contents (total and labile fractions) and the results are presented in Table 4.

The samples of biochar and biomass included in this experiment were also analyzed for the heavy metals and the results are presented in Table 5.

Table 4. Total and extractable fractions of the heavy metals.

\begin{tabular}{lll}
\hline Properties & Value & \\
\hline Total Cd (mg/kg) & 1.0 & \\
Total Cu " & 44.1 & \\
Total Pb " & 14.0 & \\
Total Zn " & 34.2 & \\
\hline Extractable " & $0.005 \mathrm{M}$ DTPA extractable & $1 \mathrm{M} \mathrm{HCl} \mathrm{extractable}$ \\
\hline Cadmium & 0.03 & BDL $^{*}$ \\
Copper & 2.06 & 11.07 \\
Lead & 1.5 & 9.8 \\
Zinc & 1.00 & 21.0 \\
\hline
\end{tabular}

$\left({ }^{*} \mathrm{BDL}=\right.$ Below detection limit).

The concentrations of the heavy metals extracted with $0.005 \mathrm{M}$ DTPA from the control soil during the entire incubation periods (Table 6) were almost similar to the background levels (Table 4). The 0.005M DTPA extractability of the heavy metals ( $\mathrm{Cd}, \mathrm{Cu}, \mathrm{Pb}$ and $\mathrm{Zn}$ ) from control soils showed similar trend during the entire incubation period, i.e. an initial decrease at 30 days of incubation followed by an increase at 60 days of incubation and then again a decrease at 90 days of incubation (Figs 1(a, b, c, d). So far the treated soils are concerned, Cd concentration remained 
unchanged during the incubation period, and the concentration was also similar to that of initial level (i.e. $0.03 \mathrm{mg} / \mathrm{kg} \mathrm{Cd}$ ) (Fig. 1a. The changes in Cd concentration were very little with incubation days and these were insignificant

Table 5. Heavy metal contents of biochars and biomasses.

\begin{tabular}{llllllll}
\hline Properties & \multicolumn{3}{c}{ Biomass } & & \multicolumn{3}{c}{ Biochar } \\
\cline { 2 - 3 } \cline { 7 - 8 } & BM 1 & BM 2 & BM 3 & & BC 1 & BC 2 & BC 3 \\
\hline Total Cd (mg/kg) & 0.28 & 0.10 & BDL $^{* *}$ & & 0.68 & 1.00 & 0.98 \\
Total Cu " & 84.0 & 47.0 & 82.0 & & 393.0 & 117.0 & 61.0 \\
Total Pb " & BDL $^{* *}$ & BDL $^{* *}$ & BDL $^{* *}$ & & BDL $^{* *}$ & BDL $^{* *}$ & BDL $^{* *}$ \\
Total Zn " & 462.6 & 22.6 & 234.4 & & 498.3 & 40.6 & 145.1 \\
CEC (Cmol/kg) & 17.1 & 12.9 & 16.1 & & 20.2 & 16.0 & 17.5 \\
C/N ratio & $22: 1$ & $177: 1$ & $251: 1$ & & $63: 1$ & $185: 1$ & $116: 1$ \\
\hline
\end{tabular}

${ }^{* *} \mathrm{BDL}=$ Below detection limit.

Table 6. 0.005M DTPA extractable heavy metal contents $(\mathrm{mg} / \mathrm{kg})$ in soil after biochar and biomass applications at different incubation days.

\begin{tabular}{|c|c|c|c|c|c|c|c|c|}
\hline \multirow{3}{*}{$\begin{array}{l}\text { Incubation } \\
\text { days }\end{array}$} & \multicolumn{8}{|c|}{ 0.005M DTPA Extractable Heavy metals (mg/kg) } \\
\hline & \multirow{2}{*}{\multicolumn{2}{|c|}{$\begin{array}{c}\text { Control } \\
\left(\mathrm{T}_{\mathrm{C}}\right)\end{array}$}} & \multicolumn{3}{|c|}{ Biomass } & \multicolumn{3}{|c|}{ Biochar } \\
\hline & & & $\mathrm{T}_{\mathrm{BM} 1}$ & $\mathrm{~T}_{\mathrm{BM} 2}$ & $\mathrm{~T}_{\mathrm{BM} 3}$ & $\mathrm{~T}_{\mathrm{BC} 1}$ & $\mathrm{~T}_{\mathrm{BC} 2}$ & $\mathrm{~T}_{\mathrm{BC} 3}$ \\
\hline \multicolumn{9}{|l|}{ Cadmium } \\
\hline 30 & & 0.02 & 0.03 & 0.03 & 0.03 & 0.03 & 0.03 & 0.03 \\
\hline 60 & & 0.03 & 0.03 & 0.02 & 0.02 & 0.02 & 0.02 & 0.02 \\
\hline 90 & & 0.03 & 0.02 & 0.03 & 0.03 & 0.02 & 0.03 & 0.03 \\
\hline \multicolumn{9}{|l|}{ Copper } \\
\hline 30 & 1.94 & & 1.97 & 1.92 & 1.91 & 1.73 & 1.75 & 1.80 \\
\hline 60 & 2.13 & & 1.87 & 1.72 & 1.77 & 1.64 & 1.73 & 1.73 \\
\hline 90 & 1.86 & & 1.55 & 1.84 & 1.77 & 1.75 & 1.69 & 1.70 \\
\hline \multicolumn{9}{|l|}{ Lead } \\
\hline 30 & & 1.43 & 1.49 & 1.44 & 1.34 & 1.40 & 1.28 & 1.30 \\
\hline 60 & & 1.71 & 1.46 & 1.46 & 1.40 & 1.36 & 1.23 & 1.32 \\
\hline 90 & & 1.48 & 1.20 & 1.43 & 1.40 & 1.28 & 1.37 & 1.28 \\
\hline \multicolumn{9}{|l|}{ Zinc } \\
\hline 30 & & 0.60 & 0.67 & 0.66 & 0.65 & 0.66 & 0.60 & 0.67 \\
\hline 60 & & 1.03 & 0.83 & 0.68 & 0.64 & 0.70 & 0.76 & 0.74 \\
\hline 90 & & 0.74 & 0.56 & 0.64 & 0.74 & 0.99 & 0.75 & 0.69 \\
\hline
\end{tabular}

( $p>0.05$ for ANOVA test). The extractability of $\mathrm{Cu}$ from the biochar and biomass treated soils substantially decreased with time. However, only saw dust treated soils and rice husk biochar treated soils showed a slight increase at 90 days of incubation (Fig. 1b). Statistical analysis 
indicated that the decrease was insignificant ( $\mathrm{p}>0.05$ for ANOVA test). Pb extractability from rice husk and its corresponding biochar treated soils substantially decreased with time of incubation. Rest of the treated soils showed, in general, a decrease from the original value albeit an erratic tendency on $\mathrm{Pb}$ extractability (Fig. 1c). ANOVA test indicated that the changes in extractable $\mathrm{Pb}$ were insignificant ( $\mathrm{p}>0.05$ for ANOVA test). In the case of $\mathrm{Zn}$ extractability, rice husk, rice straw and its corresponding biochar, and saw dust biochar treated soils showed similar trend as the control, whereas after a decrease at 60 days of incubation, the Zn extractability from saw dust treated soils and rice husk biochar treated soils increased at 90 days (Fig. 1d). ANOVA test indicated that the changes in extractable Zn were not significant ( $p>0.05$ for ANOVA test). Moreover, the days of incubation also had not any substantial effect on 0.005M DTPA extractable $\mathrm{Cd}, \mathrm{Cu}, \mathrm{Pb}$ and $\mathrm{Zn}$ content $(\mathrm{p}>0.05)$ in the soil.

The t-test values indicate that biochar had some effects on the $0.005 \mathrm{M}$ DTPA extractability. There is no significant difference in the extractable Cd between the biochar and biomass treated soils. Yet, the extractable $\mathrm{Cu}, \mathrm{Pb}$ and $\mathrm{Zn}$ in most of the treatments were significantly less in biochar treated soils than the biomass treated soils with some exceptions.

According to Huq and Alam (2005), 0.005M DTPA is considered to extract the phytoavailable (labile) fraction of heavy metals. Now as far the treated soils are concerned, it is apparent that $\mathrm{Pb}$ was below the detection limit (BDL) in the biomasses and biochars. But during the incubation, $\mathrm{Pb}$ was found in the extracts where the concentration of the metal ion was close to the control value. The $0.005 \mathrm{M}$ DTPA extractable Cd was also more or less similar to the control value. It is, thus, indicative of the fact that neither biomass nor biochars had any sorptive effect on $\mathrm{Pb}$ and $\mathrm{Cd}$ present in soil as far as the labile fraction is concerned. However, it has been found that though the values of extractable $\mathrm{Cu}$ from biomass treated soils at different incubation days were very much close to the control values, yet, that of biochar treated soils were lower than the control values. Conversely, the extractable $\mathrm{Zn}$ was slightly higher in biochar treated soils than that in biomass treated soils.

$1 \mathrm{M} \mathrm{HCl}$ extracted higher amounts of the heavy metals from soil (Table 7). However, for the control soil after the incubation periods as well as before incubation, $1 \mathrm{M} \mathrm{HCl}$ extractable Cd was below the detection limit (BDL). Cu extractability from all the biochar and biomass treated soils as well as control increased at 30 days of incubation and decreased at 60 days of incubation and then increased again at 90 days of incubation (Fig. 2a). The extractable $\mathrm{Cu}$ increased in the control and biomass treated soils whereas it showed a decreasing tendency in the biochar treated soils. The ANOVA test indicated that the change in $1 \mathrm{M} \mathrm{HCl}$ extractable $\mathrm{Cu}$ was insignificant $(\mathrm{p}>0.05)$. $\mathrm{Pb}$ extractability from all the biochar and biomass treated soils and the control soil decreased at 30 days of incubation. After the decrease at 30 days, the $\mathrm{Pb}$ extractability from the control, rice straw biochar (BC2) and saw dust biochar (BC3) treated soils increased at 60 days and decreased finally at 90 days of incubation, whereas the rest of the treated soils showed decrease both at at 60 and 90 days of incubation (Fig. 2b). The statistical analysis indicated that the change in $1 \mathrm{M} \mathrm{HCl}$ extractable $\mathrm{Pb}$ was not significant ( $\mathrm{p}>0.05$ for ANOVA test). Zn extractability from all the 
biomass and biochar treated soils increased at 30 days, decreased at 60 days and again increased at 90 days of incubation (Fig. 2c). Extractable Zn in rice straw biochar (BC2) and saw dust biochar (BC3) treated soils however, decreased at 90 days of incubation. The ANOVA test indicated that the change in $1 \mathrm{M} \mathrm{HCl}$ extractable $\mathrm{Zn}$ was insignificant $(\mathrm{p}>0.05)$. However, the days of incubation had substantial effect on $1 \mathrm{M} \mathrm{HCl}$ extractable $\mathrm{Cd}, \mathrm{Cu}, \mathrm{Pb}$ and $\mathrm{Zn}$ content $(\mathrm{p}<0.05)$ in the soil.

Table 7. 1M HCl extractable heavy metal contents $(\mathrm{mg} / \mathrm{kg})$ in soil after biochar and biomass applications at different incubation days.

\begin{tabular}{|c|c|c|c|c|c|c|c|}
\hline \multirow{3}{*}{$\begin{array}{l}\text { Incubation } \\
\text { days }\end{array}$} & \multicolumn{7}{|c|}{ 1M HCl Extractable Heavy metals (mg/kg) } \\
\hline & \multirow{2}{*}{$\begin{array}{c}\text { Control } \\
\left(\mathrm{T}_{\mathrm{C}}\right)\end{array}$} & \multicolumn{3}{|c|}{ Biomass } & \multicolumn{3}{|c|}{ Biochar } \\
\hline & & $\mathrm{T}_{\mathrm{BM} 1}$ & $\mathrm{~T}_{\mathrm{BM} 2}$ & $\mathrm{~T}_{\mathrm{BM} 3}$ & $\mathrm{~T}_{\mathrm{BC} 1}$ & $\mathrm{~T}_{\mathrm{BC} 2}$ & $\mathrm{~T}_{\mathrm{BC} 3}$ \\
\hline \multicolumn{8}{|l|}{ Cadmium } \\
\hline 30 & BDL & BDL & BDL & BDL & BDL & BDL & BDL \\
\hline 60 & BDL & BDL & BDL & BDL & BDL & BDL & BDL \\
\hline 90 & BDL & BDL & BDL & BDL & BDL & BDL & BDL \\
\hline \multicolumn{8}{|l|}{ Copper } \\
\hline 30 & 17.32 & 18.22 & 18.24 & 17.89 & 17.38 & 17.83 & 17.48 \\
\hline 60 & 9.47 & 9.09 & 9.73 & 9.77 & 14.75 & 12.53 & 14.21 \\
\hline 90 & 10.82 & 10.40 & 9.77 & 9.94 & 7.14 & 10.24 & 10.51 \\
\hline \multicolumn{8}{|l|}{ Lead } \\
\hline 30 & 2.66 & 2.66 & 2.50 & 2.33 & 2.50 & 2.66 & 2.50 \\
\hline 60 & 4.00 & 2.00 & 1.17 & 1.17 & 1.08 & 4.83 & 4.50 \\
\hline 90 & 1.83 & 0.58 & 1.42 & 1.33 & 1.08 & 1.00 & 1.08 \\
\hline \multicolumn{8}{|l|}{ Zinc } \\
\hline 30 & 32.25 & 33.45 & 33.91 & 37.28 & 32.65 & 33.19 & 32.76 \\
\hline 60 & 16.88 & 19.37 & 18.86 & 17.91 & 18.07 & 19.17 & 19.00 \\
\hline 90 & 23.28 & 20.62 & 22.13 & 19.05 & 18.16 & 18.03 & 18.33 \\
\hline
\end{tabular}

The effect of biochar and biomass on $1 \mathrm{M} \mathrm{HCl}$ extractable metal ions were verified with t-test. The t-test values indicate that biochar had some effects on the $1 \mathrm{M} \mathrm{HCl}$ extractability. There is no significant difference in the extractable $\mathrm{Cd}$ and $\mathrm{Pb}$ between the biochar and biomass treated soils. However, the extractable $\mathrm{Cu}$ in most of the treatments was significantly higher in biochar treated soils than the biomass treated soils, with some exceptions.

According to ANZECC and ARMCANZ (2000), 1M HCl extracts "weak acid extractable" fractions of metals. $1 \mathrm{M} \mathrm{HCl}$ extracted $\mathrm{Cu}$ and $\mathrm{Zn}$ from the treated soils including control. From Fig. $2 \mathrm{a}$, b and c, it is apparent that the $1 \mathrm{M} \mathrm{HCl}$ extractable $\mathrm{Pb}$ and $\mathrm{Cu}$ content is slightly higher in biochar treated soils than that in biomass treated soils. On the other hand, the $1 \mathrm{M} \mathrm{HCl}$ extractable $\mathrm{Zn}$ in biomass treated soils were slightly higher than that in the biochar treated soils, and even 
lower than the control soil. The $1 \mathrm{M} \mathrm{HCl}$ extractable $\mathrm{Pb}$ contents were lower than that of the background level $(9.82 \mathrm{mg} / \mathrm{kg})$, but that of $\mathrm{Cu}$ and $\mathrm{Zn}$ contents were higher than that of initial background level (11.07 Cu mg/Kg and $20.95 \mathrm{Zn} \mathrm{mg/Kg}$, respectively). As $\mathrm{Pb}$ was not detectable in biomasses and biochars, $1 \mathrm{M} \mathrm{HCl}$ probably extracted the $\mathrm{Pb}$ from the treated soil which was present initially in the soil. The soil had a total $\mathrm{Pb}$ content of $14.0 \mathrm{mg} / \mathrm{Kg}$ of which $9.8 \mathrm{mg} / \mathrm{Kg}$ was $1 \mathrm{M} \mathrm{HCl}$ extractable in the background level.It appears that after the incubation, this extractable amount of $\mathrm{Pb}$ decreased both in biomass and biochar treated soil. Both $\mathrm{Cu}$ and $\mathrm{Zn}$ were present in higher amount in biomass and biochars. $1 \mathrm{M} \mathrm{HCl}$ extracted not only a portion of these metals present in soils but also a portion present in the biomass and biochar applied to the soils as well. According to Beesley et al. (2011), biochars are able to complex metal ions on their surfaces and therefore, reduce bioavailability. But in our study we found that biochar released metals not only from their own surface areas but also from the soils after application.

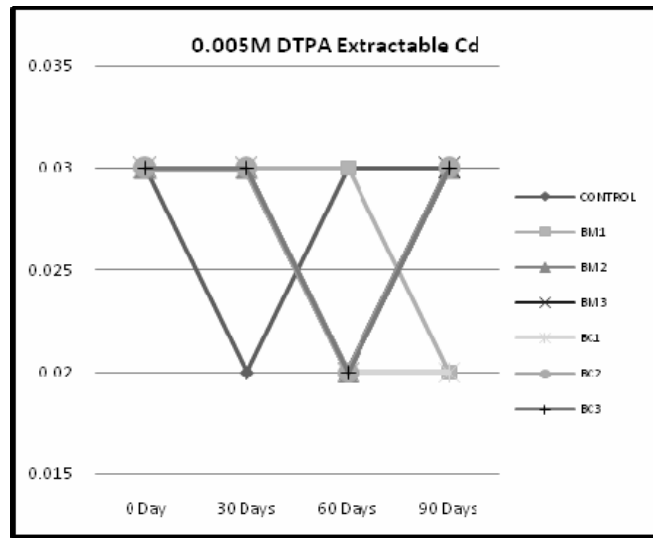

(a)

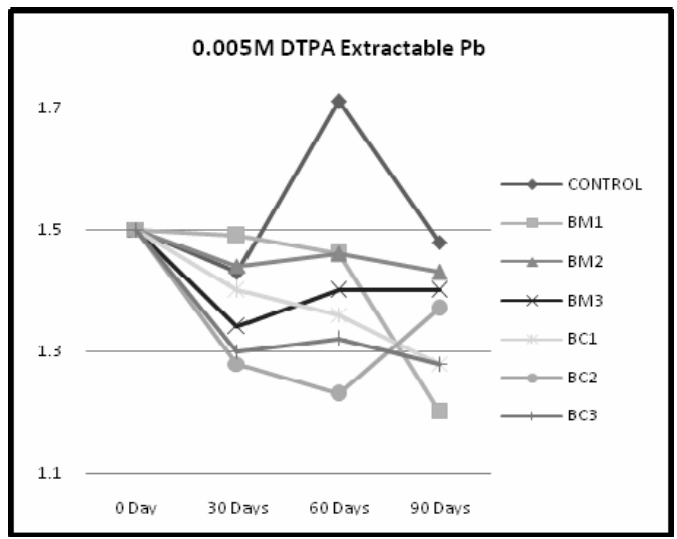

(c)

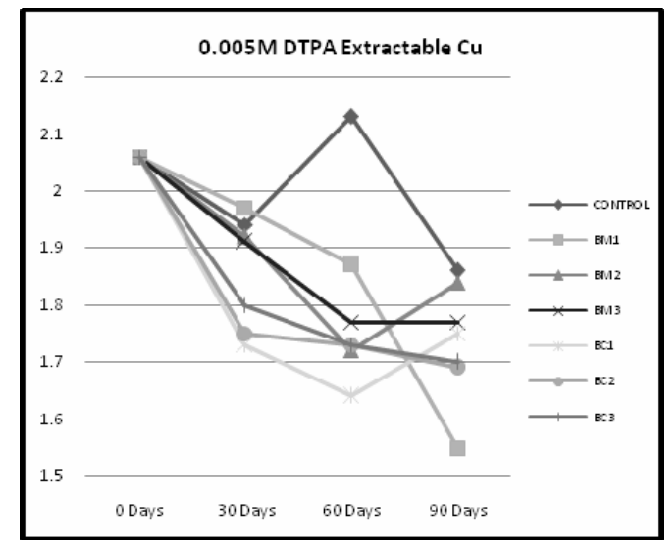

(b)

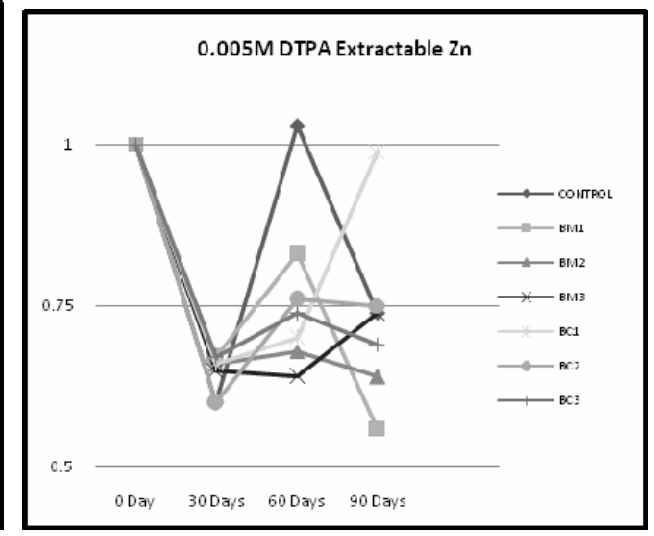

(d)

Fig. 1. Effect of biochar and biomass applications on 0.005M DTPA extractable (a) Cd, (b) $\mathrm{Cu}$, (c) $\mathrm{Pb}$ and (d) $\mathrm{Zn}$ in soil at different incubation days. 


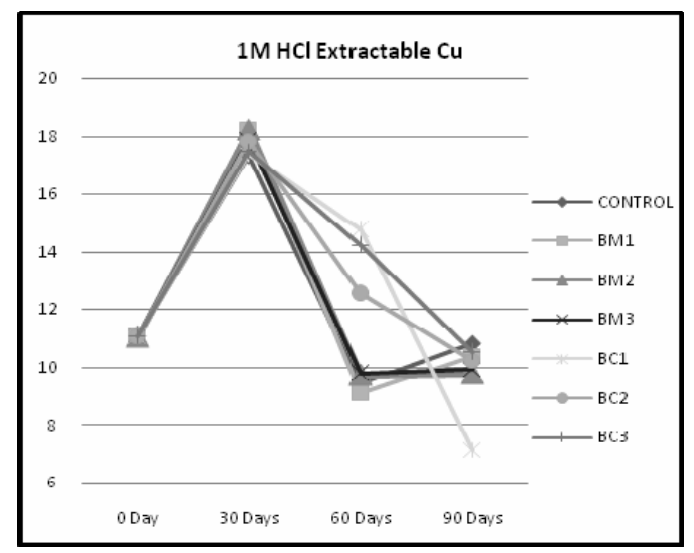

(a)

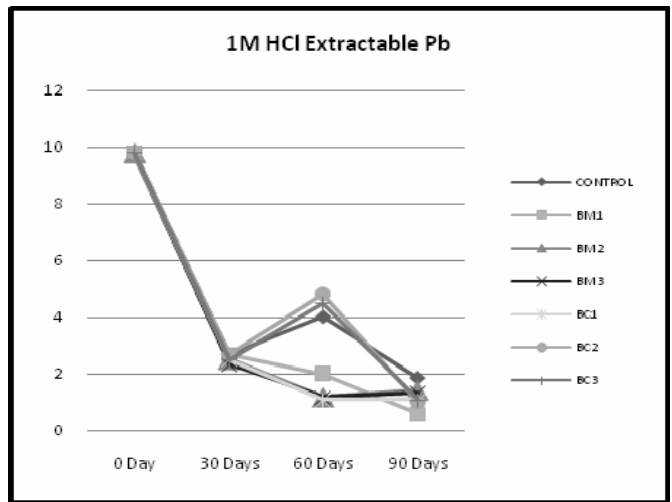

(b)

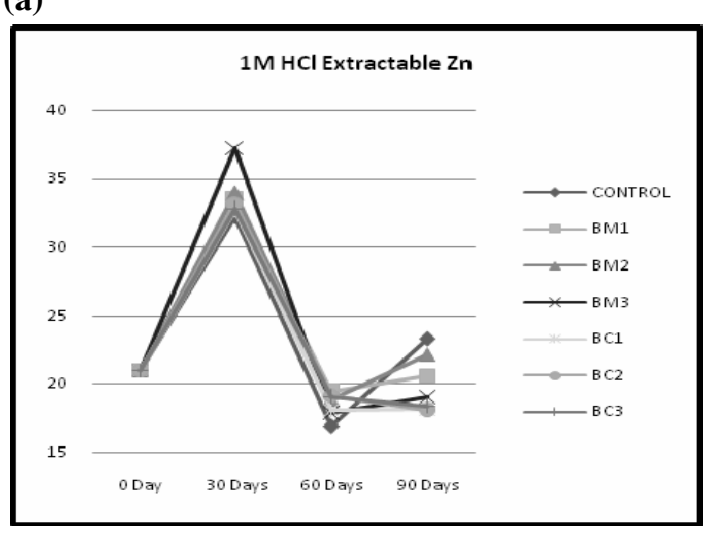

(c)

Fig. 2. Effect of biochar and biomass applications on $1 \mathrm{M} \mathrm{HCl}$ extractable (a) $\mathrm{Cu}$, (b) $\mathrm{Pb}$ and (c) $\mathrm{Zn}$ in soil at different incubation days.

\section{Conclusion}

The phytoavailable $\mathrm{Cd}, \mathrm{Cu}, \mathrm{Pb}$ and $\mathrm{Zn}$ extracted by the $0.005 \mathrm{M}$ DTPA revealed the fact that biochar did not show any substantial retainability of these metals. As expected, the $1 \mathrm{M} \mathrm{HCl}$ extracted higher amounts of heavy metals than 0.005M DTPA. Neither biomass nor biochars had any sorptive effect on $\mathrm{Pb}$ and $\mathrm{Cd}$ present in soil as far as the labile fraction is concerned. $1 \mathrm{M} \mathrm{HCl}$ extracted not only a portion of these metals present in soils but also a portion present in the biochar and biomass applied to the soils.In conclusion, it can be said that as is found in different literature about the effect of biochars on soil heavy metals that the effect is not conclusive was also apparent in the present study. Further detailed studies with biochars prepared from different sources and under different conditions are underway to ascertain the actual effect and mechanism of behavior of biochar towards soil heavy metals. 


\section{References}

ANZECC and ARM-CANZ, 2000. Australian and New Zealand Guidelines for Fresh and Marine Water Quality. Australian and New Zealand Environment and Conservation Council and Agriculture and Resource Management Council of Australia and New Zealand, Canberra. Chapter 3. pp. 1-103.

Beesley, L., E. Moreno-Jiménez, and J.L.Gomex-Eyles. 2010. Effects of biochar and greenwaste compost amendments on mobility, bioavailability and toxicity of inorganic and organic contaminants in a multi element polluted soil. Environ. Poll. 158(6): 2282-2287.

Beesley, L., E, Moreno-Jiménez, J. L. Gomex-Eyles, E. Harris, B. Robinson, and T. Sizmur. 2011. A review of biochars' potential role in the remediation, revegetation and restoration of contaminated soil. Environ. Poll. 159: 3269-3282.

Cao, X.D., L.Ma, Y.Liang, B.Gao, and W.Harris, 2011. Simultaneous immobilization of lead and Atrazine in contaminated soils using dairy-manure biochar. Environ. Sci. Technol.45: 4884-4889.

Cui, L., L. Li, A. Zhang, G.Pan, D. Bao and A. Chang. 2011. Biochar amendment greatly reduces Rice Cd uptake in a contaminated paddy soil: A two - year field experiment. BioResources 6(3): 2605-2618.

Huq, S. M. Imamul and M. D Alam, 2005. A Handbook on Analyses of Soil, Plant, and Water. BACER-DU, University of Dhaka, Bangladesh. pp. xxii-246.

Khan, T. F and S. M. Imamul Huq, 2014. Effect of Biochar on the Abundance of Soil Bacteria. British Microbiology Research Journal. 4(9): 896-904.

Khan, K. T., M.T.A. Chowdhury and S.M. Imamul Huq, 2014. Application of Biochar and fate of soil nutrients. Bangladesh J. Sci. Res. 27(1): 11-25.

Lindsay, W.L. and W.A. Norvell, 1978. Development of DTPA soil test for zinc, iron, manganese and copper. Soil Sci.Soc. Amer. J. 42: 421-428.

Mahmud, Kishan, M. S. Chowhdhury, Nadia Noor and S. M. Imamul Huq, 2014. Effects of different sources of biochar application on the emission of a number of gases from soil. Canadian J. Pure App. Sci. (CJPAS), 8(2): 2813-2824.

Masulili, A., W. H. Utomoto and M.S. Syechfani. 2010. Rice husk biochar for rice based cropping system in Acid soil. The characteristics of rice husk biochar and its influence on the properties of acid sulfate soils and rice growth in West Kalimantan, Indonesia. J. Agric. Sci. 2(1): 40-47.

Web1: Frontpage. Gardening with Biochar FAQ. http://biochar.pbworks.com/w/page/9748043/FrontPage 